\title{
Abbreviations and Referencing
}

Throughout the text, references to Joyce's works are from the following editions:

Poems and Shorter Writings, ed. Richard Ellmann, A. Walton Litz and John Whittier-Ferguson (London: Faber, 2001), abbreviated as PSW. Stephen Hero, rev'd edn (London: Jonathan Cape Ltd, 1956), abbreviated as $\mathrm{SH}$.

Dubliners, ed. Jeri Johnson (Oxford: Oxford University Press, 2000), abbreviated as $D$.

A Portrait of the Artist as a Young Man, ed. Jeri Johnson (Oxford: Oxford University Press, 2000), abbreviated as $P$.

Giacomo Joyce (London: Faber, 1983), abbreviated as GJ.

Exiles (London: Jonathan Cape, 1972), abbreviated as E.

Ulysses, ed. Jeri Johnson (Oxford: Oxford University Press, 1998), abbreviated as $U$.

Finnegans Wake (London: Faber and Faber, 1975), abbreviated as FW.

Occasional, Critical and Political Writings, ed. Kevin Barry (Oxford: Oxford University Press, 2000), abbreviated as OCP.

Critical Writings of James Joyce, ed. Ellsworth Mason and Richard Ellmann (London: Faber, 1959), abbreviated as CW.

Letters of James Joyce, vol. 2, ed. Richard Ellmann (London: Faber and Faber, 1966), abbreviated as $L$.

References to Homer's The Odyssey are taken from the translation by Richmond Lattimore: The Odyssey of Homer (New York: HarperPerennial, 1991).

The choice of Johnson's edition of Ulysses in particular merits a brief discussion. The textual history of Ulysses is a matter of considerable controversy. Ulysses was originally published by Shakespeare and Company in February 1922. Joyce complained upon the novel's publication that 
the edition contained a significant quantity of textual errors, and, when Harriet Weaver brought out a second edition for the English market in October 1922, a printed list of 'Errata' was included within its pages. Unfortunately this new edition contained a new set of misprints, and the textual condition of the novel was not markedly improved. The situation was complicated still further when Samuel Roth brought out his pirated and bowdlerised edition of Ulysses in America in 1926; although Roth was legally compelled to desist from printing soon afterward, his corrupt version of Ulysses became the template for the 1934 Random House edition of the novel and remained the standard American edition until 1961. A 1932 Odyssey Press edition of Ulysses, prepared by Joyce's friend Stuart Gilbert, sought to bring a degree of order to a chaotic situation, but was later found to contain a not insignificant number of textual errors of its own.

By the 1960s there were a number of editions of Ulysses in circulation, each of which was found to contain a quantity of textual errors. The situation was briefly stabilised in 1961, when Random House brought out its own 'corrected edition', but the status of this new edition was subsequently called into question (Dalton 1972). In 1984 the German textual critic Hans Walter Gabler sought to resolve the various textual issues in dispute by issuing his new 'corrected text' of Ulysses. Gabler's edition attempted to overcome the problems engendered by the corrupt 1922 edition by returning to Joyce's original manuscript, complete with all its additions, variants and revisions, and treating it as a continuous manuscript text. Although initially acclaimed, the integrity of Gabler's edition has come under repeated challenge over the last twenty years, and both his practices and conclusions remain a matter of intense scholarly debate.

Gabler's 'corrected text' remains a valuable scholarly resource, and should certainly be consulted for insights into Joyce's compositional practice, but it remains difficult to obtain in Britain. Declan Kiberd's Penguin edition is widely available, but its text reprints the relatively corrupt Bodley Head edition of 1960. The best version of Ulysses under these circumstances is Jeri Johnson's Oxford World Classics edition, which contains a useful introductory essay alongside a wealth of bibliographical and critical material. It also includes a succinct and detailed account of Ulysses' textual history, expertly rehearsing and summarising many of the issues outlined here (Joyce 1998: xxxviii-lvi). 